\title{
Breeding Practices and Traits Preferences of Goat Keepers at Lepelle- Nkumpi Local Municipality, South Africa: Implication for the Design of Breeding Programs
}

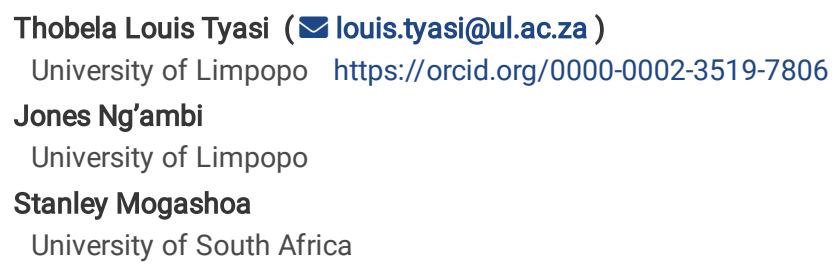

Version of Record: A version of this preprint was published at Tropical Animal Health and Production on January 19th, 2022. See the published version at https://doi.org/10.1007/s11250-022-03078-x. 


\section{Abstract}

Identification of breeding practices and traits preferences by farmers for selection of breeding animals to be parents of the next generations is the crucial step to the successful implementation of community-based breeding programs (CBBPs). The aim of the study was to detect breeding practices and traits preferences by farmers at Lepelle-Nkumpi Local Municipality, South Africa to determine their relevance in establishing a CBBPs. A structural questionnaire was designed and administered to 183 randomly selected goat keepers from 4 villages. Across the 4 communities, the majority of goat keepers were males with the traditional purposes, sales and meat production as their main reasons of keeping goats. Spring breeding season was practiced using natural mating system controlled mainly by means of castration and culling of poor reproductive or undesired goats for breeding. The most important common farmers' preference traits among the four communities were twining ability, good mothering ability and body size in breeding does, and mating ability, growth rate and body size in breeding bucks. However, the selection of breeding stock might also include qualitative traits such as coat color of goats. The results from this study are useful for designing CBBPs for indigenous goats in Lepelle-Nkumpi Local Municipality.

\section{Introduction}

South Africa is known to be a comparatively small-scale goat producing country whereby it holds about $1 \%$ in the world's listings of the goats' numbers and in Africa is only $3 \%$, Eastern Cape has more goats accounting for $38 \%$ followed by Limpopo with $17 \%$, KwaZulu Natal with $13 \%$ and North West $12 \%$ (DAFF, 2019). In South Africa, goats are kept by commercial and communal farmers (Slayi et al., 2014; Mdladla et al., 2017). Commercial farmers keep Red Kalahari, Savannah and Boer goats for meat production, Saanen and Toggenburg goats for milk production and Angora goats for mohair production (Gwaze et al., 2009). Communal farmers mostly keep indigenous goats to fulfil multiple roles that include manure, traditional ceremonies, skin, milk, meat and bush encroachment control (Saico and Abul, 2007; Gwaze et al., 2010; Chokoe et al., 2020). South Africa has more than six million indigenous goats raised by communal farmers (Chokoe et al., 2020). However, communal indigenous goat farmers have poor production systems due to lack of breeding knowledge for genetic improvement of livestock to increase the production (Yakubu et al., 2019). A community-based breeding program is a process of breeding that requires a bottom-up approach where the people responsible for genetic improvement of livestock should ask the farmers questions about their animals to understand farmers' situations before designing the pro-gram (Nandolo et al., 2016). Community-based breeding programs (CBBPs) attempt to achieve the genetic improvement of animals through direct participation of farmers (Ouedraogo et al., 2020; Zoma-Traore et al., 2021). Knowing traditional farmers' breeding objectives and traits preferences helps development of CBBPs (Berhanu et al., 2012; Fantahun et al., 2016; Yakubu et al., 2020). Breeding objectives aid the farmers to define the directions towards satisfying their demand to increase the profit (Wurzinger et al., 2011). Therefore, farmers need improvement of their production systems and CBBPs have gained attention as a promising method for the genetic improvement of small ruminants (Manirakiza et al., 2020). Several studies have been conducted in developing countries goat farmers to identify breeding objectives and practices, traits and breed preference and selection criteria of communal goat farmers with the intention of designing a CBBPs. The studies were conducted in Jordan (Tabbaaa and Al-Atiyatb, 2009), Hamer and Bena Tsemay districts of Ethiopia (Berhanu et al., 2012), Loma district of Southern Ethiopia (Lorato et al., 2015), Bela Zone and Oromia in Ethiopia (Asefa et al., 2015), Bench Maji zone in South western Ethiopia (Fantahun et al., 2016), Loma district of Ethiopia (Lorata et al., 2016), Malawi (Nandolo et al., 2016), Uganda (Onzima et al., 2018), Western Tigrey, North Ethiopia (Abraham et al., 2018), West Shoa zone, Ejere and Barga districts of Ethiopia (Meme, 2016), Arab and Oromo regions, north-western Ethiopia (Sheriff et al., 2020), Hai district, Northern Tanzania (Nguluma et al., 2020) and Pakistan (Ramzan et al., 2020). However, based on our knowledge there is limited studies on breeding objectives and trait preferences by South African goat farmers. Hence, the current study was conducted to investigate the breeding practices and trait preferences of indigenous goat farmers with implication for the design of breeding programs.

\section{Materials And Methods Description of the study area}

The study was conducted in Lepelle-Nkumpi Local Municipality, Capricorn District Municipality of Limpopo province, South Africa. Lepelle-Nkumpi Local Municipality is located at $24.2585^{\circ} \mathrm{S}$ latitude and $29.6499^{\circ} \mathrm{E}$ longitude (Fig. 1). The mean annual rainfall is between $453 \mathrm{~mm}$ and $474 \mathrm{~mm}$ with the rainfall coefficient variable at $30.78 \%$. This coefficient variation indicates that rainfall is rather stale from year to year. The average annual rainfall patterns also correspond directly to the temperature patterns, revealing that the northern part of the municipality has higher average rainfall patterns (between 800 and $1200 \mathrm{~mm}$ ) and thus greater potential for agricultural activities than the Southern part with average annual rainfall patterns of between 400 and $600 \mathrm{~mm}$ per annum. The mean annual temperature is approximately $20^{\circ} \mathrm{C}$ with an average summer temperature of $23^{\circ} \mathrm{C}$ and average winter temperature of $20^{\circ} \mathrm{C}$. The mean annual temperatures in the northern half of the area is slightly cooler with average temperatures ranging between minus 14 and 17 degrees Celsius compared to the South where average temperatures range between 19 to 20 degrees Celsius. There are overwhelming majority of livestock species within the Capricorn District, which are goats (44\%), followed by cattle (38\%), pigs (10\%) and sheep (9\%). Nearly all the goats in the Capricorn District (98\%) are communally farmed. Thus, the existing livestock farming in Lepelle-Nkumpi Local Municipality involves goats, cattle, sheep and poultry. Livestock farming activity in Lepelle Nkumpi Local Municipality is one of the key sub-categories of agriculture with goat production being the most popular form of livestock farming. The vegetation in Lepelle-Nkumpi Municipality is predominantly Savannah Biome (grasses with dispersed trees and shrubs) (Kuyamandi Development Services, 2006).

\section{Sampling techniques and sample size}


The study was conducted following the cross-sectional study design method. A multi-stage sampling procedure was employed whereby Lepelle-Nkumpi Local Municipality was purposively selected as the first stage since the Department of Agriculture, Land Reform and Rural Development in Limpopo indicated that this local municipality has a higher population of indigenous goats, and then four villages were randomly selected namely Morotse, Sepitsi, Malekapane and Semiloane. A total one hundred and eighty-three $(n=183)$ goat farmers were randomly selected at Morotse $(n=65)$, Sepitsi $(n=51)$, Malekapane $(n=36)$ and Semiloane $(n=31)$ and given questionnaires per village.

\section{Data collection}

Data was collected on farmers' breeding knowledge and socioeconomic profile through face to face interviews using a semi-structured questionnaire which was designed as described by (Haile et al., 2011). The questionnaire was pre-tested in 5 farmers per village to check whether all the questions were adequate, clear and understandable. Data was collected on household characteristics including respondent's age, gender, age, education level, size of the household and source of income and breeding experiences on purpose of keeping goats, selection criteria of breeding stock, breeding objectives and practices. The questionnaire was administered to individual household head responsible for goat farming but all the members of the household were allowed to add any relevant information. A total of 183 respondents were interviewed in April, 2021 to achieve the study. Identification of selection criteria for breeding stock, trait preferences and coat color preferences were done in a participatory manner as explained by (Dunguma et al., 2011). Briefly, respondents were provided with the list of ten (10) traits and were asked to choose the traits preferred for the selection of breeding stock. However, the respondents were asked to add any additional traits which were not in the list.

\section{Data analysis}

Data was analyzed using Statistical Package for the Social Sciences version 27 (SPSS, 2020). Selection criteria, coat color and trait preferences were calculated for the importance of each criterion and estimated by computing the index of ranking as explained by (Zewdu et al., 2018). Index = Sum ( $3 x$ rank1 +2 x rank2 $+1 \times$ rank3) for individual trait / Sum $(3 \times$ rank1 $+2 \times$ rank2 $+3 \times$ rank1) for overall traits.

\section{Results}

\section{Goat farmers' characteristics}

A summary of the socioeconomic characteristics of respondents is presented in Table 1. At Morotse, out of 65 respondents surveyed the majority of them (58\%) were males with the age ranging from 50 to 70 years at $43 \%$, married (94\%) and most that which attained a secondary and above education ( $95 \%$ ). At Sepitsi, out of 51 respondents the majority of them (55\%) were males with the age ranging from 50 to 70 years (48\%), married (92\%) and most accomplished secondary and above education (96\%). At Malekapane, out of 36 respondents the majority of them (58\%) were males with the age ranging from 50 to 70 years (47\%), married (97\%) and most obtained secondary and above education (94\%). At Semiloane, out of 31 respondents the majority of them $(61 \%)$ were males with the age ranging from 50 to 70 years (45\%), married (97\%) and most achieved secondary and above education ( $94 \%)$.

\section{Purpose of keeping goats}

Reasons for keeping goats in the study area are summarised in Fig. 2. Purposes for keeping goats differed slightly among villages. At Morotse, the main reasons given were traditional purposes (29\%), sales (22\%), meat production (18\%), security (12\%) and milk production (8\%). At Sepitsi, the respondents kept goats for meat production (22\%), traditional purposes (18\%), security (18\%) and sales (14\%). At Malekapane, the main purposes given by respondents were meat production (25\%), traditional purposes (22\%), social status (17\%) and security (14\%). In Semiloane, the main reasons given were meat production (29\%), traditional purposes (29\%), sales (19\%), social status (6\%) and security (6\%).

\section{Goats herd size}

The information on the number of goats kept by respondents is presented in Table 2. Morotse kept 2413.00 goats, with the average of 37.12 goats per respondent and the minimum of 10.00 and maximum of 63.00 goats. The majority of respondents (43.08\%) kept a herd of above 40 goats and the smallest proportion (20\%) keeping a herd of below 20 goats. Sepitsi respondents kept 1714.00 goats, with an average of 34.32 goats per respondent, with a minimum of 9.00 and a maximum of 70.00 goats. The highest herd size (37.25\%) of goats kept by farmers was above 40 goats and the lowest proportion (27.45\%) herd size was between 21 and 40 goats. Malekapane households kept 1059.00 goats with the average of 29.42 goats per household, with the minimum of 10.00 and a maximum of 55.00 goats. Semiloane households kept 1064.00 goats, with the average of 33.6 goats per household, a minimum of 10.00 and maximum of 62.00 goats in a herd, the majority of respondents (41.09\%) kept herds of between 21 and 40 goats, while the lowest herds $(24.81 \%)$ kept goats below 21 goats in a herd.

\section{Breeding practices}

The summary of breeding practices of the goat keepers is presented in Table 3 . The results indicated that most of the goat keepers bred their animals in spring with $76.92 \%, 76.47 \%, 86.11 \%$ and $87.10 \%$ at Morotse, Sepitsi, Malekapane and Semiloane communities, respectively. All the goat keepers (100\%) in the study practiced a natural mating system. Majority of the households controlled the mating with castration and culling (38.46\%), castration (49.02\%), culling $(50.00 \%)$ and culling (41.94\%) at Morotse, Sepitsi, Malekapane and Semiloane communities, respectively. Grazing together of goats in the 
community veld was the predominantly reason (41.54\%, $44.44 \%$ and $51.61 \%)$ for goat keepers not to control their mating at Morotse, Malekapane and Semiloane, respectively, while at most goat keepers were not controlling mating due to lack of awareness (47.06\%) at Sepitsi community. The majority of goat keepers kept the breeding bucks (52.31\% and 58.33\%) at Morotse and Malekapane communities, respectively, while the majority were not keeping breeding bucks (64.71\% and $77.42 \%$ ) at Sepitsi and Semiloane communities, respectively, and about $47.69 \%, 58.82 \%, 47.22 \%$ and $67.74 \%$ of goat keepers kept their bucks for mating with the majority having indigenous bucks. The majority of goat keepers depended on the community for breeding bucks $(49.02 \%, 44.44 \%$ and $54.84 \%)$ at Sepitsi, Malekapane and Semiloane communities, respectively, while the majority of goat keepers at Morotse depended on buying $(40.00 \%)$ the breeding bucks. About $58.46 \%, 72.55 \%, 77.78 \%$ and $67.74 \%$ of goat keepers culled their goats by slaughtering, mainly due to old age $(32.31 \%, 43.14 \%)$ at Morotse and Malekapane, respectively, while goat keepers at Sepitsi and Semiloane communities culled due to poor reproductive performance $(50.00 \%$ and $38.71 \%$, respectively).

\section{Goat keepers' trait preferences for breeding does}

The summary of the relative importance of traits as ranked by surveyed respondents for selection of breeding does is presented in Table 5 . Index was used for computing the importance of the traits. The results indicated that twinning ability $(0.303)$, body size $(0.277)$ and mothering ability $(0.154)$ were considered as important traits at Morotse community. At Sepitsi community, twinning ability (0.333), body size (0.314) and mothering ability (0.176) were rated as significant traits. Twinning ability (0.343), body size (0.343) and mothering ability $(0.157)$ were considered as important traits in Malekapane village. At Semiloane community, body size (0.366), twinning ability $(0.333)$ and mothering ability (0.075) were recognised as vital traits. Overall, twinning ability (0.328), body size (0.325), mothering ability (0.141), temperament $(0.065)$, age at first kidding ( 0.051$)$, kidding ability (0.051) and coat colour (0.039) were recognised as the important traits in all the communities.

\section{Goat keepers' trait preferences for breeding bucks}

Table 5 summarises the relative importance of traits as ranked by goat keepers for selection of breeding bucks. The findings showed that mating ability (0.308), body size (0.305), growth rate (0.228) and temperament (0.079) were considered as important traits in Morotse community. At Sepitsi community, mating ability (0.327), body size (0.317), growth rate (0.245) and coat colour (0.078) were valued as noteworthy traits. Body size (0.394), mating ability (0.310), growth rate (0.185) and coat colour (0.093) were considered as important traits at Malekapane village. At Semiloane community, body size (0.301), mating ability $(0.274)$, growth rate $(0.253)$ and coat colour $(0.108)$ were recognised as remarkable traits. Overall, body size $(0.329)$, mating ability (0.305), growth rate $(0.228)$, temperament $(0.037)$, coat colour $(0.082)$ and horns $(0.019)$ were indicated as the important traits in all the sites.

\section{Discussion}

Identification of breeding practices and traits preferred by communal farmers is the important step to the successful implementation of breeding programs for communal goat farmers (Ouedraogo et al., 2020). Socioeconomic characteristics of the surveyed Lepelle-Nkumpi local municipality goat keepers have been documented in this study. The results revealed that men were the majority of goat keepers and that this was expected due to traditional and cultural customary patterns of South African rural people which believe that a man is the head of the household and likely to have a final say in issues related to keeping of livestock. The attached ownership to the goats in the cur-rent study is comparable with the findings of (Onzima et al., 2018) who revealed that the majority (84.8\%) of farmers keeping indigenous goats in Uganda are males, and (Sheriff et al., 2020) who also observed that most (67.5\%) of farmers keeping indigenous goats in Hani district of Northern Tanzania were males. The distribution of ownership of livestock species be-tween sexes (men and female) influences the type of livestock raised by the community (Bravo-Baumann, 2000). For instance, cattle, sheep, goat, donkeys and horses are commonly owned by males while pigs and poultry are commonly owned by females (Sheriff et al., 2020). Most of the goat keepers interviewed in this study were at the secondary and above levels of education which indicates that goat keeping as part of agriculture is practiced by the literates. Thus, it might be easy to train them to practice the new approach such as a CBBPs for improvement of their goats. This remark disagrees with the result of (Mtshali et al., 2021) who showed that goat keepers in North West province of South Africa were mainly literate with formal primary education $(77.1 \%$ ) while those with secondary education level were at $45.7 \%$, and those with tertiary education level were at $2.9 \%$. The present study has revealed that there is a variation in the average number of goats kept per household at Morotse (23.12), Sepitsi (34.32), Malekapane (29.42) and Semiloane (33.61). These findings are comparable with the studies of reported large flock sizes at Hamer (63.2), Dasenech (37.1) and Benatsemay (54.7) (Biruh et al., 2017), and at Abergelle (48.5) (Abegaz et al., 2013). On the other hand, small flock sizes were reported in Ethopia at Arab (11.2) and Oromo (9.9) (Sheriff et al., 2020), Metema (10.8) (Abegaz et al., 2013), Meanit Shata (18.75), Sheko (6.10) and Shey Bench (4.55) (Fantahum et al., 2016). Previous research findings from South Africa revealed that the average number of indigenous goats kept by respondents in North West province was 19.9 (Mdladla et al., 2017) and 21 (Mtshali et al., 2021) and in KwaZulu-Natal it was 17.4 (Mahlobo, 2016). A small number of animals per household could be problematic for selection during breeding and might increase inbreeding and reduce genetic gain (Abebe et al., 2020). Therefore, the goat keepers with a small number of goats must establish collaboration with other goat keepers to create a large breeding herd for sustainable use of genetic resources. Large flock sizes observed in the current study are realized as one of the encouraging factors of selection at the goat keepers' level for designing the CBBPs. Across the communities surveyed in the current study, indigenous goats of South Africa played a multifaceted role with the farmers. Although indigenous goats played a multipurpose role across the communities, meat production, traditional purposes and sales were considered the overriding goals of keeping goats. The present finding is consistent with other studies conducted in the developing countries that underscore the importance of goats in making an income (Fantahun et al., 2016; Lorato et al., 2015; Onzima et al., 2018; Lorato et al., 2016; Onzima et al., 2016; Sheriff et al., 2020; Nguluma et al., 2020). According to Mtshali et al. (2021), the goat keepers in South Africa sell their goats to generate income. Surveyed goat keepers in the present study do not consider milk as the primary purpose of raising the goats. This outcome is in disagreement with previous studies (Abraham et al., 2018; Kosgey et al., 2008; Hassen and Tesfaye, 2014) but agree with other studies (Dubeuf, 2010; Legese et al., 2014; Dossa et al., 2015). The main 
reason for farmers in the present study not to consider the importance of goat milk might be the lack of awareness in nutritional and medicinal values of goat milk. It is vital to consider the reasons of keeping goats before designing the breeding program since the importance of farmers' attributes to the multipurpose use of goats recommends that CBBPs might have a good probability of achievement in the studied communities. Valuing indigenous information is important to ensure the sustainability of a breeding program planned to be implemented at the community level (Abebe et al., 2020). As expected, the majority of goat keepers in the studied communities have been practicing natural mating system due to lack of artificial insemination knowledge. The majority of farmers in the studied communities were not controlling the mating because their goats were grazing together in the communal grazing rangelands. This result is consistent with the findings of (Lorato, 2016) who stated that the majority of goat keepers in lowland, midland and highland areas of Loma district in Ethiopia do not control mating and the main reason of not controlling mating was that goats of the community graze together. The present study is in disagreement with the report of (Nguluma et al., 2020) who reported that the majority of goat keepers in Hai district in Northern Tanzania control mating using the apron technique in males. Apron technique was reported by (Peacock, 1996) as an effective traditional way of control-ling mating by trapping it around the buck's waist which then blocks him from being able to breed with female goats until the famer decides to remove it to allow breeding. According to Ngulama et al. (2020), the effectiveness of the apron technique is difficult for communal farmers since it needs to be frequently checked and most farmers are occupied by multiple functions. Although the majority of goat keepers in the present study were not controlling mating, some of them were controlling the mating through castration. Castration is a good practice as it increases fat deposition, makes the animal friendly and docile (Kebede et al., 2008). The farmers in the current study might practice castration since it is the better option to control mating and prohibits inbreeding. According to Gkarane et al. (2017), farmers castrate their animals in order to remove smell from the meat and improve meat quality. According to Haile et al. (2011) males not selected for breeding must be castrated through the consensus of the community members sharing the grazing sites to implement a successful CBBPs. Con-trolled mating is vital for genetic improvement of animals as it enables farmers to avoid non-selective mating and inbreeding. The advantage of controlled mating is that only selected animals will pass on their genes to the next herd generation for genetic improvement. However, studied communities where the goats are grazing together in the community veld controlled mating might be difficult. The majority of goat keepers depend on the community for breeding bucks. This result is similar to the findings of (Meme, 2016) who found that the majority of farmers were depending on the community for breeding bucks in Ada Barga and Ejere districts of West Shoa zone, Oromia, Ethiopia. Since most of the surveyed farmers depend on the community for breeding bucks and goat are grazing together, the implementation of a breeding program in such communities needs to involve the whole community. Participation of farmers in evaluating breeding practices and designing breeding programs is vital for achievement of live-stock improvement programs (Mueller et al., 2015). Onzima et al. (2018) reported that the use of preferences based on farmers' weightings of traits has become a powerful tool for livestock farmers to rank their animals. Several studies in Africa have used participatory method to give information for implementation of CBBPs for goat keepers (Fantahun et al., 2016; Lorato, 2016; Onzima et al, 2018; Meme, 2016; Sheriff et al., 2020; Ramzan et al., 2020; Lorato, 2017; Bett et al, 2009; Gebreyesus et al., 2013). Across the three communities in the present study, body size, mothering ability and twinning ability for breeding does while mating ability, body size and growth rate for breeding bucks were considered very important by goat keepers. Body size was the most preferred traits in breeding does and bucks in Ada Barga and Ejere districts of Ethiopia (Meme, 2016), western Tigray of Ethiopia (Abraham et al., 2018), Arab and Oromo in north-western Ethiopia (Sheriff et al., 2020). In the recent study with indigenous goats in South Africa, goat keepers similarly preferred body size and growth rate for breeding does and bucks (Mtshali et al., 2021). Our findings on trait preferences of breeding bucks and does emphasizes the importance of body size and growth rate, goat keepers preferred these traits since the market prefers the body size, thus the larger the body size the higher the price and the faster growing animal reaches the market weight sooner. Twinning ability was ranked as an important trait in the selection of breeding does (Fantahun et al., 2016; Lorato, 2015; Sheriff et al., 2020). The preference of twinning ability for the selection of breeding does indicates the genetic potential of South African indigenous goats in the studied communities for multiple births to increase flock size. These results are contrary to the report of (Nguluma et al., 2020) who found that coat color was ranked as an important trait for the choices of breeding bucks and does. Coat color is a qualitative trait which cannot be measured on a scale basis. CBBPs in the study communities should be focused towards body size, mothering ability, twinning ability, growth rate and mating ability. However, qualitative traits like coat color also need to be considered for sustainable breeding programs. In conclusion, South African indigenous goat farmers at Lepelle-Nkumpi local municipality had different reasons of keeping goats, breeding practices and trait preferences for their breeding goats of the next generations. The use of defined reasons of keeping goats, breeding practices and trait preferences by goat keepers is crucial for improvement of goat performance. Participatory approach employed in the current study might be useful in identifying reasons of keeping animals, breeding practices and farmers' preferences traits and important for a sustainable breed improvement program for indigenous goats. Goat keepers in the study communities have shown their highest preference for twinning ability, body size and good mothering ability in breeding does, and good mating ability, body size and growth rate in breeding bucks. Reasons of keeping goats, breeding practices and trait preferences identified in the current study need to be considered in designing and implementing of CBBPs in the studied communities.

\section{Declarations}

Funding: This research was funded by the University of Limpopo Niche Area grant (UL Niche area 2020/21).

Conflicts of Interest: Authors declare that they have no conflict of interest regarding the information provided in this manuscript.

Availability of data and material: The data presented in the current study are available on request from the corresponding author.

Author Contributions: Conceptualization: T.L.T., J.N. and S.M. Methodology: T.L.T. and S.M. Validation: J.N. Data analysis: T.L.T. Investigation: T.L.T. Resources: T.L.T. and S.M. Data curation: T.L.T. and S.M. Writing-original draft preparation: T.L.T. and S.M. Writing-review and editing: J.N. Visualization: T.L.T. and S.M. Supervision: J.N. Project administration: T.L.T. and S.M. Funding acquisition: T.L.T. All authors have revised and agreed to the submitted version of the manuscript. 
Acknowledgments: Authors are thankful for funding from the University of Limpopo (UL Niche area 2020/21) through short projects. We greatly acknowledge field enumerators and government extension officers at the communities visited for data collection. We are, also, thankful to the goat keepers of Morotse, Sepitsi, Malekapane and Semiloane communities who spent their invaluable time to provide the data for the current study.

Ethical approval: Before the study started, collection of the data procedures and structures were revised and approved by Turfloop Research Ethics Committee (TREC) of the University of Limpopo, South Africa (number TREC/25/2021:IR) which was held on the 17th of February, 2021. Respondents were given the consent form to sign for taking part in the study.

\section{References}

1. Abebe, A.S., Alemayehu, K., Johansson, A.M. and Gizaw, S., 2020. Breeding practices and trait preferences of smallholder farmers for indig nous sheep in the northwest highlands of Ethiopia: Inputs to design a breeding program. PLoS ONE.,15, e0233040.

2. Abegaz, S.G., Sölkner, J., Gizaw, G., Dessie, T., Haile, A. and Wurzinger, M., 2013. Description of production systems and morphological characteristics of Abergelle and Western lowland goat breeds in Ethiopia: implication for community-based breeding programs. Anim. Genet. Res., 53, 69-78.

3. Abraham, H., Gizaw, S. and Urge, M., 2018. Identification of breeding objectives for Begait goat in western Tigray, North Ethiopia. Trop. Anim. Health Prod., 50(8), 1887-1892.

4. Asefa, B., Kebede, K. and Effa, K., 2015. Breeding objectives, selection criteria and breeding system of indigenous goat types in bale zone, Oromia, Ethiopia. Int. J. Agri. Res. Innov. Tech., 5 (2): 7-15.

5. Berhanu, T., Thiengtham, J., Tudsri, S., Abebe, G., Tera, A. and Prasanpanich, S., 2012. Purposes of keeping goats, breed preferences and selection criteria in pastoral and agro-pastoral districts of South Omo Zone. Livest. Res. Rural Dev., 24(12), 20.

6. Bett, R.C., Kosgey, I.S., Kahi, A.K. and Peters, K.J., 2009. Analysis of production objectives and breeding practices of dairy goats in Kenya. Trop. Anim. Health Prod., 41, 307-320.

7. Biruh, T., Kefelegn, K. and Kefena, E. 2017., Traditional goat husbandry practice under pastoral systems in South Omo zone, southern Ethiopia. Trop. Anim. Health. Prod., 49, 625-632.

8. Bravo-Baumann, H., 2000. Livestock and gender: A winning pair, Swiss Agency for Development and Cooperation. Available from http:// www.fao.org/WAIRDOCS/LEAD/X6106E/X6106E00.HTM.

9. Chokoe, T.C., Matelele, T.C., Maqhashu, A., Ramukhithi, F.V., Mphahlele, T.D., Mpofu, T.J., Nephawe, K.A. and Mtileni, B., 2020a. Phenotypic Diversity of South African Indigenous Goat Population in Selected Rural Areas. Am. J. Anim. Vet. Sci.,15, 59-66.

10. Chokoe, T.C., Mdladla-Hadebe, K., Muchadeyi, F., Dzomba, E., Matelele, T., Mphahlele, T., Mpofu, T.J., Nephawe, K. and Mtileni, B., 2020b. Genetic Diversity of South African Indigenous Goat Population from Four Provinces Using Genome-Wide SNP Data Sustainability.,12, 10361.

11. Department of Agriculture, Forestry and Fisheries (DAFF)., 2019. A profile of the South African goat market value chain. Republic of South Africa, DAFF Annual Report. Available at http://www.daff.gov.za/.

12. Dossa, L.H., Sangaré, M., Buerkert, A.C. and Schlecht, E., 2015. Production objectives and breeding practices of urban goat and sheep keepers in West Africa: regional analysis and implications for the development of supportive breeding programs. Springer Plus., 4, 281.

13. Duguma, G., Mirkena, T., Haile, A., Okeyo, A.M., Tibbo, M., Rischkowsky, B., Sölkner, J. and Wurzinger, M., 2011. Identification of smallholder farmers and pastoralists' preferences for sheep breeding traits: Choice model approach. Anim. Int. J. Anim. Biosci., 5, 1984-1992.

14. Dubeuf, J.P., 2010. Characteristics and diversity of the dairy goat production systems and industry around the world. Structural, market and organizational conditions for their development. Tecnol Ciên. Agropec., 4, 25-31.

15. Fantahun, T., Alemayehu, K. and Abegaz, S., 2016. Characterization of goat production systems and trait preferences of goat keepers in Bench Maji zone, south western Ethiopia. African J. Agric. Res., 11(30), 2768-2774.

16. Gebreyesus, G.A., Haile, A. and Dessie, T., 2013. Breeding scheme based on community-based participatory analysis of local breeding practices, objectives and constraints for goats around Dire Dawa, Ethiopia. Livest. Res. Rural Dev., 25(3):48.

17. Gwaze, F., Chimonyo, M. and Dzama, K., 2009. Communal goat production in Southern Africa: a review. Trop. Anim. Health. Prod., 41, 1157-1168.

18. Gwaze, F., Chimonyo, M. and Dzama, K., 2010. Estimation of goat production potential and efficiency in the resource-poor communal areas of the Eastern Cape Province of South Africa. Trop. Anim. Health Prod., 42, 1235-1242.

19. Haile, A., Wurzinger, M., Mueller, J., Mirkena, T., Duguma, G., Okeyo Mwai, A., Sölkner, J. and Rischkowsky, B.A., 2011. Guidelines for Setting Up Community-Based Sheep Breeding Programs in Ethiopia: Lessons and Experiences for Sheep Breeding in Low-Input Systems, 2nd ed.; ICARDA: Beirut, Lebanon.

20. Hassen, A.S. and Tesfaye, Y., 2014. Sheep and goat production objectives in pastoral and agro-pastoral production systems in Chifra district of Afar, Ethiopia. Trop. Anim. Health. Prod., 46, 1467-1474.

21. Gkarane, V., Allen, P., Gravador, R.S., Diskin, M.G., Claffey, N.A., Fahey, A.G., Brunton, N.P., Farmer, L.J., Moloney, A.P. and Monahan, F.J., 2017. Effect of castration and age at slaughter on sensory perception of lamb meat. Small Rumin. Res., 157, 65-74.

22. Kayamandi Development Services., Goat meat production feasibility study., 2006. http://www.lepelle-nkumpi.gov.za/lepelle nkumpiadmin/pages/sites/lepellenkumpi/documents/strategies/GOAT\%20FA RMING\%20FEASIBILITY.pdf. 
23. Kosgey, I.S., Rowlands, G.J., van Arendonk, J.A.M. and Baker, R.L., 2008. Small ruminant production in smallholder and pastoral/ extensive farming systems in Kenya. Small Rumin. Res., 77, 11-24.

24. Kebede, T., Lemma, T., Dinka, H., Guru, M. and Sisay, A., 2008. Growth performance and carcass characteristics of Arsi-Bale goats castrated at different ages. J. Cell Anim. Biol., 2, 187-194.

25. Legese, G., Haile, A., Duncan, A.J., Dessie, T., Gizaw, S. and Rischkowsky, B., 2014. Sheep and goat value chains in Ethiopia: A synthesis of opportunities and constraints. ICARDA/ILRI Project Report. Nairobi, Kenya: International Center for Agricultural Research in the Dry Areas/ International Livestock Research Institute.

26. Lorato, Y., Ahmed, K.M. and Belay, B., 2015. Participatory Characterization of the Woyto-Guji goat and its production environment around Northern Omo, Ethiopia. J. Agric. Natural Res. Sci. 2015, 2(2), 455-465.

27. Lorato, Y., 2016. Production objectives, breeding practices and selection criteria of indigenous goat in Loma District. Global J. Anim. Sci. Res., 4(3), 19-27.

28. Lorato, Y., Ahmed, K.M. and Birhanu, B., 2017. Participatory identification of breeding objective traits of Woyto-Guji goat in Loma district, Southern Ethiopia. Inter. J. Livest. Prod., 8(8), 131-135.

29. Mahlobo, B.T., 2016. Multi - criteria livestock assessment for sustainability of smallholder farms in Kwa-Zulu Natal. Masters Thesis. Stellenbosch University

30. Manirakiza, J., Hatungumukama, G., Besbes, B. and Detilleu, J., 2020. Characteristics of smallholders' goat production systems and effect of Boer crossbreeding on body measurements of goats in Burundi. Pastoralism., 10:2.

31. Mdladla, K., Dzomba, E.F. and Muchadeyi, F.C., 2017. The potential of landscape genomics approach in the characterization of adaptive genetic diversity in indigenous goat genetic resources: A South African perspective. Small Rumin. Res., 150, 87-92.

32. Meme, Y., 2016. Study of Productive and Reproductive Performances and Farmers' Traits Preferences for Breeding of Small Ruminants in Ada Barga and Ejere Districts of West Shoa Zone, Oromia, Ethiopia. Adv. Life Sci. Tech., 49: 1-10.

33. Mtshali, T.F., Mapholi, O.N., Ncube, K.T., Dzomba, E.F., Matelele, T.C., Chokoe, T.C., Mphahlele, T.D., Muchadeyi, F.C. and Hadebe, K., 2021. Goat farmers' production objectives and trait preferences in the North West province of South Africa: An approach to identify selection criteria for community-based breeding programs. Intern. J. Livest. Prod., 12(2), 64-75.

34. Mueller, J.P., Rischkowsky, B., Haile, A., Philipsson, J., Mwai, O., Besbes, B., Valle Zarate, A., Tibbo, M., Mirkena, T., Duguma, G. and et al., 2015. Community-based livestock breeding programs: Essentials and examples. J. Anim. Breed. Genet.,132, 155-168.

35. Nandolo, W., Wurzinger, M., Gabor, M., Van Tassell, C., Gondwe, T., Mulindwa, H., Lamuno, D. and Sölkner, J., 2016. Identification of breeding objectives in community based goat breeding programmes in Malawi 2016. Acta Agric. Slov., 5, 104.

36. Nguluma, A.S., Hyera, E., Nziku, Z., Shirima, E.M., Mashingo, M.SH., Lobo, R.N.B., Getachew, T., Rischkowsky, B. and Haile, A., 2020. Characterization of the production system and breeding practices of indigenous goat keepers in Hai district, Northern Tanzania: implications for community-based breeding program. Trop. Anim. Health Prod., 52, 2955-2967.

37. Onzima, R.B., Gizaw, S., Kugonza, D.R., van Arendonk, J.A. and Kanis, E., 2018. Production system and participatory identification of breeding objective traits for indigenous goat breeds of Uganda. Small Rumin. Res., 163, 51-59.

38. Ouedraogo, D., Soudre, A., Ouedrago-Kone, S., Zoma, B.L., Yougbare, B., Khayatzadeh, N., Burger, P.A., Meszaros, G., Traore, A., Mwai, O.A. and et al., 2020. Breeding objectives and practices in three local cattle breed production systems in Burkina Faso with implication for the design of breeding programs. Livest. Sci., 232, 103910.

39. Peacock, C.P. 1996. Improving Goat Production in the Tropics: A Manual for Development Workers., (Oxfarm/Farm Africa, London).

40. Ramzan, F., Khan, M.S., Bhatti, S.A., Gültas, M., Armin, O. and Schmitt, S., 2020. Breeding objectives and selection criteria for four strains of Pakistani Beetal goats identified in a participatory approach. Small Rumin. Res., 190, 106163.

41. Saico, S.S. and Abul, S., 2007. Socio-economic constraints on goat farming in the lowveld of Swaziland-A case study of Matsanjeni. J. Sust. Dev. Africa., 9, 37-49.

42. Sheriff, O., Alemayehu, K. and Haile, A., 2020. Production systems and breeding practices of Arab and Oromo goat keepers in northwestern Ethiopia: implications for community-based breeding programs. Trop. Anim. Health Prod., 52:1467-1478.

43. Slayi, M., Maphosa, V., Fayemi, O.P. and Mapfumo, L., 2014. Farmers' perceptions of goat kid mortality under communal farming in Eastern Cape, South Africa. Trop. Anim. Health Prod., 46:1209-1215.

44. SPSS., 2020. IBM Corp. Released 2020. IBM SPSS Statistics for Windows, Version 27.0. IBM Corp., Armonk, NY.

45. Tabbaaa, J.M. and Al-Atiyatb, R., 2009. Breeding objectives, selection criteria and factors influencing them for goat breeds in Jordan. Small Rumin. Res., 84, 8-15.

46. Wurzinger, M., Solkner, J. and Iniguez, L., 2011. Important aspects and limitations in considering community-based breeding programs for low-input smallholder livestock systems. Small Rumin. Res., 98, 170-175.

47. Yakubu, A., Dahloum, L. and Gimba, E.G., 2019. Smallholder cattle farmers' breeding practices and trait preferences in a tropical guinea savanna agro-ecological zone. Trop. Anim. Health Prod., 51: 1497-1506.

48. Yakubu, A., Isaa, S., Alabib, O., Shoyombob, A.J. and Adeolu, A.I., 2020. Breeding practices and trait preferences of sheep farmers in a Sub-Humid tropical environment. Trop. Anim. Sci. J., 43(4), 377-384. 
49. Zewdu, A., Alemayehu, K. and Zewdu, W., 2018. Breeding practices and farmers Trait Preferences on indigenous dairy cattle production in East Gojjam Zone, Ethiopia. Asian J. Agric. Food Sci., 6(1), 55-63.

50. Zoma-Traoré, B., Probst, L., Ouédraogo-Koné, S., Soudré, A., Ouédraogo, D., Yougbaré, B., Traoré, A., Khayatzadeh, N., Mészáros, G., Burger, P.A. and et al., 2021. Livestock keepers' attitudes: keystone of effective community-based breeding programs. Sustainability.,13, 2499.

\section{Tables}

Table 1 Socioeconomic characteristics of the respondents.

\begin{tabular}{llllll}
\multirow{2}{*}{ Factor } & Level & \multicolumn{3}{l}{ Communities (\%) } & \\
\cline { 2 - 6 } & & Morotse & Sepitsi & Malekapane & Semiloane \\
\hline \multirow{2}{*}{ Sex } & Male & 58 & 55 & 58 & 61 \\
\cline { 2 - 6 } & Female & 42 & 42 & 42 & 39 \\
\hline \multirow{2}{*}{ Age } & $<50$ yrs & 31 & 28 & 28 & 29 \\
\cline { 2 - 6 } & $50-70$ yrs & 43 & 48 & 47 & 45 \\
\cline { 2 - 6 } & $>70$ yrs & 26 & 24 & 25 & 26 \\
\hline Educational level & No formal & 5 & 4 & 6 & 6 \\
\cline { 2 - 6 } & Primary & 0 & 0 & 0 & 1 \\
\cline { 2 - 6 } & Sec \& abv & 95 & 96 & 94 & 94 \\
\hline Marital status & Single & 5 & 4 & 3 & 3 \\
\cline { 2 - 6 } & Married & 94 & 92 & 97 & 97 \\
\cline { 2 - 6 } & Widow & 2 & 4 & 0 & 0 \\
\hline
\end{tabular}

$\%$ : Percentage, <: Below, >: Above, yrs: Years, Sec \& abv: Secondary and above.

Table 2 Proportion of respondents indicating goat herd size.

\begin{tabular}{|c|c|c|c|c|c|c|c|}
\hline Community & No of goats & Mean & $\min$ & $\max$ & $<21$ goats & 21 - 40 goats & $>40$ goats \\
\hline Morotse & 2413.00 & 37.12 & 10.00 & 63.00 & $20.00 \%$ & $36.92 \%$ & $43.08 \%$ \\
\hline Sepitsi & 1714.00 & 34.32 & 9.00 & 70.00 & $35.29 \%$ & $27.45 \%$ & $37.25 \%$ \\
\hline Malekapane & 1059.00 & 29.42 & 10.00 & 55.00 & $33.33 \%$ & $55.56 \%$ & $11.11 \%$ \\
\hline Semiloane & 1064.00 & 33.61 & 10.00 & 62.00 & $25.81 \%$ & $41.94 \%$ & $32.26 \%$ \\
\hline
\end{tabular}

No: number, Min: Minimum, Max: Maximum. <: Less than, >: More than.

Table 3 Proportions of goat keepers for breeding practices. 


\begin{tabular}{|c|c|c|c|c|}
\hline \multirow[t]{2}{*}{ Breeding practice } & \multicolumn{4}{|c|}{ Community } \\
\hline & Morotse & Sepitsi & Malekapane & Semiloane \\
\hline \multicolumn{5}{|l|}{ Breeding season (\%) } \\
\hline Spring & 76.92 & 76.47 & 86.11 & 87.10 \\
\hline Autumn & 23.08 & 23.53 & 13.89 & 12.90 \\
\hline \multicolumn{5}{|l|}{ Mating methods (\%) } \\
\hline Natural & 100.00 & 100.00 & 100.00 & 100.00 \\
\hline Artificial insemination (Al) & 0.00 & 0.00 & 0.00 & 0.00 \\
\hline \multicolumn{5}{|l|}{ Control mating (\%) } \\
\hline Yes & 47.69 & 62.75 & 52.78 & 58.06 \\
\hline No & 52.31 & 37.25 & 47.22 & 41.94 \\
\hline \multicolumn{5}{|l|}{ Methods of controlling mating (\%) } \\
\hline Castration & 30.77 & 49.02 & 33.33 & 38.71 \\
\hline Culling & 30.77 & 21.57 & 50.00 & 41.94 \\
\hline Castration and culling & 38.46 & 29.41 & 16.67 & 19.35 \\
\hline \multicolumn{5}{|l|}{ Reasons for not control mating (\%) } \\
\hline Goats grazing together & 41.54 & 21.57 & 44.44 & 51.61 \\
\hline Lack of awareness & 20.00 & 47.06 & 25.00 & 19.35 \\
\hline Goats grazing together and lack of awareness & 38.46 & 31.37 & 30.56 & 29.03 \\
\hline \multicolumn{5}{|l|}{ Keep breeding bucks (\%) } \\
\hline Yes & 52.31 & 35.29 & 58.33 & 22.58 \\
\hline No & 47.69 & 64.71 & 41.67 & 77.42 \\
\hline \multicolumn{5}{|l|}{ Reasons of keeping bucks (\%) } \\
\hline Mating & 47.69 & 58.82 & 47.22 & 67.74 \\
\hline Fattening & 27.69 & 29.41 & 36.11 & 22.58 \\
\hline Mating and fattening & 24.62 & 11.76 & 16.67 & 9.68 \\
\hline \multicolumn{5}{|l|}{ Breeds of breeding bucks (\%) } \\
\hline Indigenous & 69.23 & 58.82 & 72.22 & 87.10 \\
\hline Exotic & 30.77 & 41.18 & 27.78 & 12.90 \\
\hline \multicolumn{5}{|l|}{ Source of breeding bucks (\%) } \\
\hline Own & 32.31 & 39.22 & 30.56 & 29.03 \\
\hline Community & 27.69 & 49.02 & 44.44 & 54.84 \\
\hline Purchase & 40.00 & 11.76 & 25.00 & 16.13 \\
\hline \multicolumn{5}{|l|}{ Reasons of culling (\%) } \\
\hline Poor reproductive & 26.15 & 7.84 & 50.00 & 38.71 \\
\hline Undesired body confirmation & 7.69 & 11.76 & 27.78 & 6.45 \\
\hline Diseases & 9.23 & 5.88 & 8.33 & 0.00 \\
\hline Older & 32.31 & 43.14 & 13.89 & 32.26 \\
\hline Undesired coat colour & 24.62 & 31.37 & 0.00 & 22.58 \\
\hline \multicolumn{5}{|l|}{ Culling method (\%) } \\
\hline Selling & 32.31 & 11.76 & 16.67 & 22.58 \\
\hline Slaughtering & 58.46 & 72.55 & 77.78 & 67.74 \\
\hline Exchange & 9.23 & 15.69 & 5.56 & 9.68 \\
\hline
\end{tabular}


$\%$ : Percentage.

Table 4 Ranks and indices for trait preference in breeding bucks.

\begin{tabular}{|c|c|c|c|c|c|c|c|c|c|c|c|c|c|c|c|c|c|}
\hline \multirow[t]{2}{*}{ Trait } & \multicolumn{4}{|c|}{ Morotse $(n=65)$} & \multicolumn{4}{|c|}{ Sepitsi $(n=51)$} & \multicolumn{4}{|c|}{ Malekapane $(n=36)$} & \multicolumn{4}{|c|}{ Semiloane $(n=31)$} & \multirow[b]{2}{*}{$\begin{array}{l}\text { Overal } \\
\text { index }\end{array}$} \\
\hline & R1 & R2 & R3 & Index & R1 & $\mathrm{R} 2$ & R3 & Index & R1 & R2 & R3 & Index & R1 & R2 & R3 & Index & \\
\hline Mating ability & 20 & 25 & 10 & 0.308 & 16 & 20 & 12 & 0.327 & 11 & 12 & 10 & 0.310 & 9 & 10 & 4 & 0.274 & 0.305 \\
\hline Body size & 25 & 12 & 20 & 0.305 & 20 & 12 & 13 & 0.317 & 16 & 14 & 9 & 0.394 & 11 & 8 & 7 & 0.301 & 0.329 \\
\hline Horns & 0 & 1 & 9 & 0.028 & 0 & 0 & 5 & 0.016 & 0 & 0 & 0 & 0.000 & 0 & 3 & 0 & 0.032 & 0.019 \\
\hline Coat colour & 0 & 7 & 6 & 0.051 & 0 & 7 & 10 & 0.078 & 1 & 4 & 9 & 0.093 & 2 & 2 & 10 & 0.108 & 0.082 \\
\hline Growth rate & 17 & 15 & 8 & 0.228 & 14 & 12 & 9 & 0.245 & 8 & 6 & 4 & 0.185 & 9 & 6 & 8 & 0.253 & 0.228 \\
\hline Temperament & 3 & 5 & 12 & 0.079 & 1 & 0 & 2 & 0.016 & 0 & 0 & 4 & 0.019 & 0 & 2 & 2 & 0.032 & 0.037 \\
\hline
\end{tabular}

R1-R3: Rank 1 to Rank 3, n: sample size.

Table 5 Ranks and indices for trait preference in breeding does.

\begin{tabular}{|c|c|c|c|c|c|c|c|c|c|c|c|c|c|c|c|c|c|}
\hline \multirow[t]{2}{*}{ Traits } & \multicolumn{4}{|c|}{ Morotse $(n=65)$} & \multicolumn{4}{|c|}{ Sepitsi $(n=51)$} & \multicolumn{4}{|c|}{ Malekapane $(n=36)$} & \multicolumn{4}{|c|}{ Semiloane $(n=31)$} & \multirow[b]{2}{*}{$\begin{array}{l}\text { Overall } \\
\text { index }\end{array}$} \\
\hline & R1 & R2 & R3 & Index & R1 & R2 & R3 & Index & R1 & R2 & R3 & Index & R1 & R2 & R3 & Index & \\
\hline $\begin{array}{l}\text { Twinning } \\
\text { ability }\end{array}$ & 23 & 19 & 17 & 0.303 & 20 & 17 & 14 & 0.333 & 14 & 13 & 10 & 0.343 & 12 & 10 & 9 & 0.333 & 0.328 \\
\hline Body size & 19 & 23 & 12 & 0.277 & 13 & 19 & 16 & 0.314 & 12 & 16 & 9 & 0.343 & 13 & 11 & 10 & 0.366 & 0.325 \\
\hline $\begin{array}{l}\text { Mothering } \\
\text { ability }\end{array}$ & 7 & 9 & 14 & 0.154 & 8 & 10 & 9 & 0.176 & 5 & 4 & 8 & 0.157 & 2 & 4 & 1 & 0.075 & 0.141 \\
\hline Temperament & 3 & 2 & 9 & 0.072 & 4 & 0 & 8 & 0.078 & 0 & 0 & 5 & 0.046 & 0 & 1 & 5 & 0.065 & 0.065 \\
\hline $\begin{array}{l}\text { Age at } 1^{\text {st }} \\
\text { kidding }\end{array}$ & 4 & 1 & 10 & 0.077 & 2 & 3 & 1 & 0.039 & 2 & 2 & 1 & 0.046 & 2 & 0 & 2 & 0.043 & 0.051 \\
\hline Coat colour & 3 & 5 & 0 & 0.041 & 1 & 1 & 0 & 0.013 & 1 & 0 & 3 & 0.037 & 2 & 1 & 3 & 0.065 & 0.039 \\
\hline $\begin{array}{l}\text { Kidding } \\
\text { ability }\end{array}$ & 6 & 6 & 3 & 0.077 & 3 & 1 & 3 & 0.046 & 2 & 1 & 0 & 0.028 & 0 & 4 & 1 & 0.054 & 0.051 \\
\hline
\end{tabular}

R1-R3: Rank 1 to Rank 3, n: sample size, Age at $1^{\text {st }}$ kidding: Age at first kidding.

Figures 


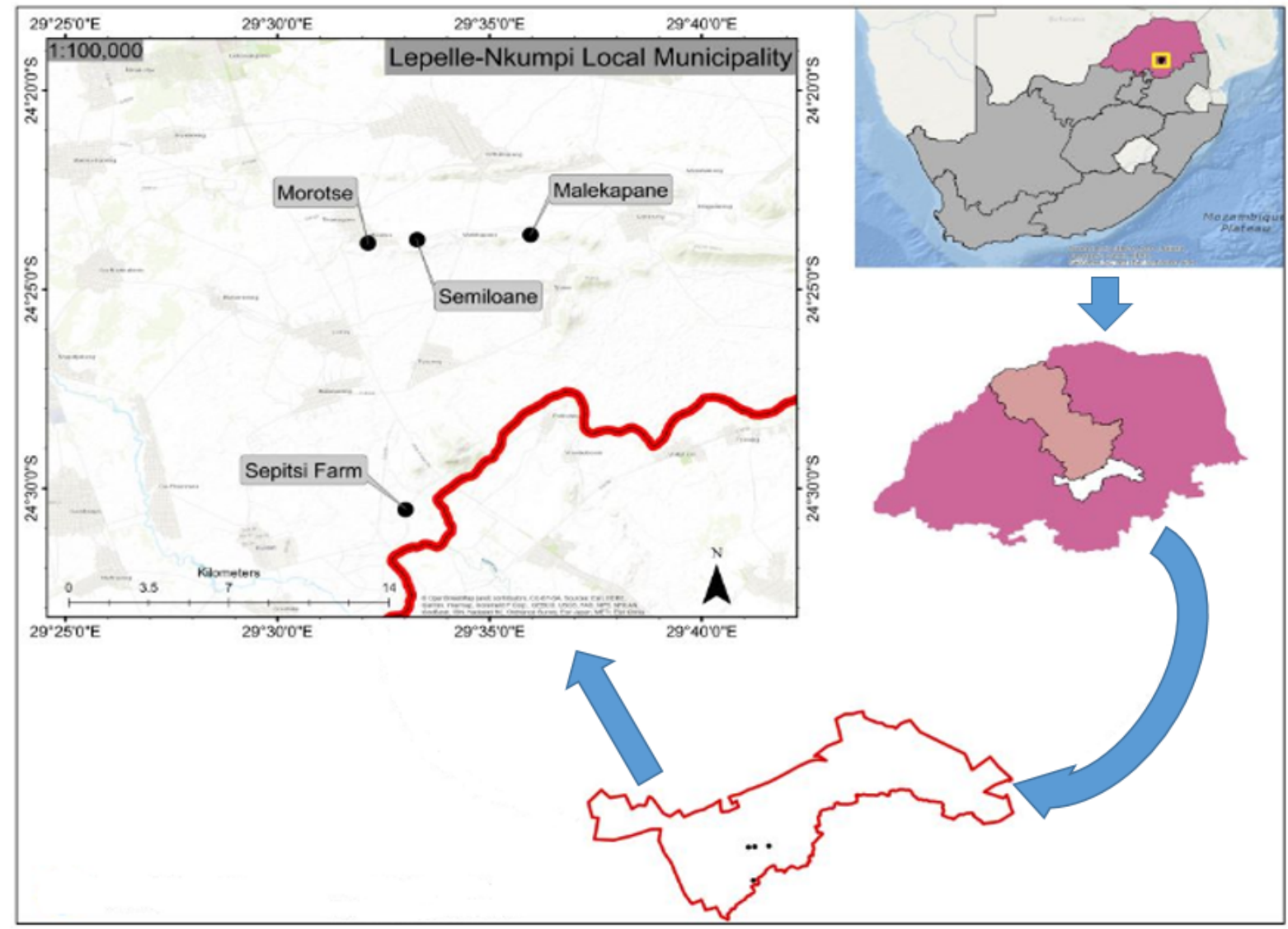

Figure 1

South African map showing study areas.

35

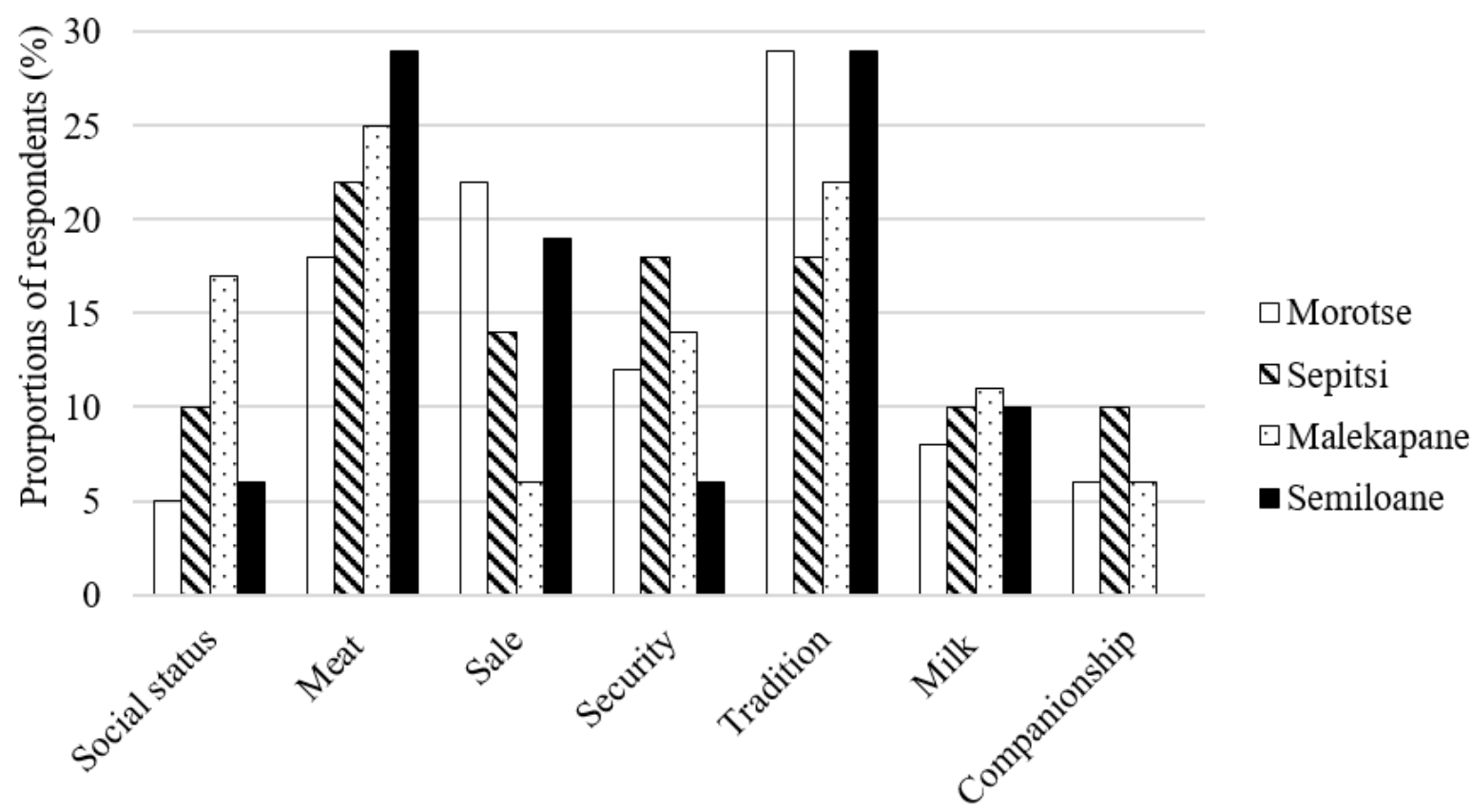

Reasons of keeping goats

Figure 2

Proportions of respondents keeping goats for particular reasons across communities. 